\title{
DOES PRIOR DANTROLENE AFFECT THE IN VITRO DIAGNOSIS OF MALIGNANT HYPERTHERMIA SUSCEPTIBILITY?
}

\author{
T.E. Nelson and E.H. Flewellen
}

THE ONLY UNEQUIVOCAL TEST at present for malignant hyperthermia susceptibility (MHS) is an in vitro pharmacological test of skeletal muscle ${ }^{3-6}$. Skeletal muscle from malignant hyperthermia-susceptible individuals has abnormal contracture to halothane alone ${ }^{3.4}$ and to caffeine in the presence or absence of halothane, ${ }^{3.6}$ Any subject undergoing elective muscle biopsy for diagnosis of malignant hyper. thermia susceptibility will likely be exposed to stress and some form of anaesthesia; two factors which contribute to the risks of inducing malignant hyperthermia. It is not uncommon in our experience that a patient presenting for diagnosis of malignant hyperthermia susceptibility also has another need for surgery and general anaesthesia. Although certain anaesthetic techniques are considered safe for patients susceptible to malignant hyperthermia, the risks remain unknown. An additional safeguard against malignant hyperthermia would be the use of prophylactic agents.

Dantrolene, an unique skeletal muscle relaxant, is proven prophylactic and therapeutic for malignant hyperthermia in the pig. ${ }^{10.12}$ Dantrolene also blocks the abnormal contracture response of human MHS muscle to halothane, which supports its usefulness for malignant hyperthermia in man. It would appear, therefore, that dantrolene might provide a margin of safety for MHS patients undergoing anaesthesia. However, if these patients are having an elective muscle biopsy for diagnosis of MHS, the effect of dantrolene on the in vitro diagnostic contracture responses is unknown.

The present study was designed to test if prior dantrolene administration to MHS pigs affected the in vitro contracture responses to halothane and caffeine.

T.E. Nelson, Ph.D. Assistant Professor and E.H. Flewellen, M.D., Assistant Professor, Department of Anesthesiology. University of Texas Medical Branch. Galveston, Texas 77550, U.S.A.

Supported in part by U.S.P.H.S. NIH Grant GM23876-0.

\section{Methods}

Four littermate purebred Poland China pigs. the offspring of MHS parents, were used in the study. Each animal was biopsied at two different times. For the first biopsy, each pig was induced with thiopentone $30 \mathrm{mg} \cdot \mathrm{kg}^{-1}$, the trachea was intubated and the animals were ventilated with 100 per cent oxygen. In order to reproduce. as closely as possible, the agents used in our laboratory for patients undergoing elective biopsy for MHS diagnosis, each pig was given morphine $0.15 \mathrm{mg} \cdot \mathrm{kg}^{-1}$, and diazepam $0.6 \mathrm{mg} \cdot \mathrm{kg}^{-1}$. This was designed to mimic the premedication and induction doses given MHS diagnostic patients. Anaesthesia was maintained thereafter with thiopentone, fentanyl $0.0075 \mathrm{mg} \cdot \mathrm{kg}^{-1}$ intravenously over 5 minutes and nit rous oxide 60 per cent with oxygen.

Muscle strips were obtained from the left gracilis muscle for pre-dantrolene controls. The methods for biopsy and in vitro testing were similar to those previously described.' Halothane, when used, was added as three per cent vapour by flowing carbogen $(95$ per cent oxygen with five per cent carbon dioxide) through a calibrated Dragerwick vaporizer and bubbling the mixed gas through the muscle bath. Caffeine was added from a stock $100 \mathrm{mM}$ solution in cumulative concentrations until a cumulative contracture response of at least $2 \mathrm{~g}$ resulted. Each addition of caffeine was made when the previous caffeine contracture response reached a plateau. The specific caffeine concentration which produced a $1 \mathrm{~g}$ isometric contracture response was calculated for each muscle by regression analysis of log caffeine dose vs. cumulative contracture in grams. The halothane specific caffeine concentration was calculated for caffeine contracture in the presence of three per cent halothane as described above. Following the pre-dantrolene control biopsy. each pig was turned to the opposite side for a second contralateral biopsy following dantrolene administration. An evoked forelimb toe twitch was arranged and quantitated by methods previously described. ${ }^{2}$ After baseline 
toe twitch tension was established, a $3.5 \mathrm{mg} \cdot \mathrm{kg}^{-1}$ dose of dantrolene, which produced 9.5 per cent maximum twitch depression (Flewellen and Nelson unpublished data), was administered intravenously over a ten-minute period. This dantrolene dose has proved to be prophylactic and therapeutic for halothane-succinylcholine challenge in MHS swine (Flewellen and Nelson, unpublished). The second biopsy was performed on the right gracilis 15 minutes after the dantrolene administration was completed.

Anticipating that in vivo dantrolene would have an effect on subsequent in virro contracture responses, contracture tests were repeated for each biopsy immediately and at one and two hours after biopsy, to determine if any dantrolene effect could be washed out of the muscle during incubation periods. Times reported as zero in the text are responses obtained within ten minutes from biopsy, that is, the actual time from biopsy to treatment in vitro. Two muscle strips from each animal were exposed to a single treatment. Data were analyzed by an analysis of variance technique.

\section{REsults}

The halothane contractures for pre-dantrolene and post-dantrolene muscle at various times after biopsy are presented in Figure 1. Intravenous dantrolene $3.5 \mathrm{mg} \mathrm{kg}$ had no effect on the in vitro response of muscle strips to three per cent halothane. Only a small percentage of the total statistical variance was attributed to muscle response within pigs ( 5 per cent), with a considerable variation among animals within a treatment (22 per cent). A large percentage of the variance

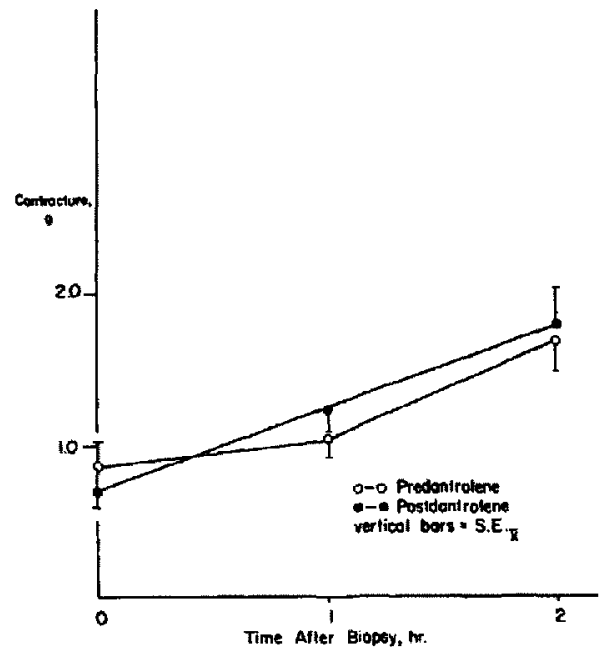

FIGURE I Effect of dantrolene and time after biopsy on halothane contractures of MHS pig muscle. Each point is the average of eight muscle strips, two per animal.

was attributed to time of testing after biopsy ( 42 per cent). Over the two-hour period after biopsy. the longer the fibers were incubated, the greater was the halothane contracture response ( $p<$ $0.005)$. Dantrolene treatment did not affect the increased halothane response with time.

Dantrolene had no significant effect on the abnormal caffeine contracture of MHS muscle (Table I). The average specific caffeine concentration calculated to produce $1 \mathrm{~g}$ isometric contracture was $2.56 \mathrm{mM}$ before and $2.60 \mathrm{mM}$ after dantrolene was administered (Figure 2). The time

TABLE 1

Effect of Dantrolene and Time After Bropsy on in vilto Caffeine Contracture of MHS MUSCLF

Caffeine Concentration, MM

\begin{tabular}{llcccc}
\hline \hline & $\begin{array}{c}\text { Time after } \\
\text { biopsy, hr }\end{array}$ & 0.5 & 1.0 & 2.0 & 4.0 \\
\hline Predantrolene & Zero & 0 & $0.25(.06)$ & $0.75(.15)$ & $1.99(.24)$ \\
& 1 & 0 & $0.09(.06)$ & $0.74(.13)$ & $2.33(.44)$ \\
& 2 & 0 & $0.11(0.6)$ & $1.03(.22)$ & $2.69(.38)$ \\
Postdantrolene & Zero & 0 & $0.05(.05)$ & $0.31(.05)$ & $1.74(.16)$ \\
& 1 & 0 & $0.04(.05)$ & $1.48(.13)$ & $2.44(.30)$ \\
& 2 & 0 & $0.14(.05)$ & $1.04(.30)$ & $3.27(.37)$ \\
\hline
\end{tabular}

*Values are average cumulative contracture tension $(\mathrm{g})$ and values in parentheses are S.E. $\bar{x}$. Each mean across caffeine concentrations is the average of eight muscle strips, two per animal. 


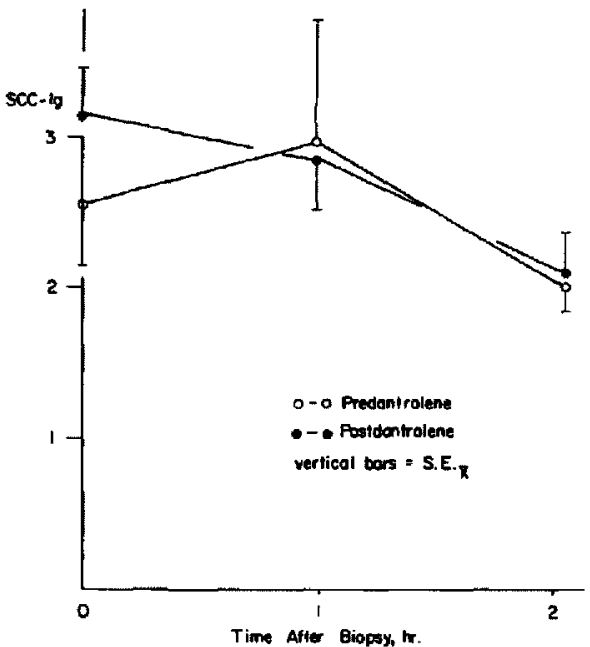

Figure 2 Effect of dantrolene and time after biopsy on $1 \mathrm{~g}$ specific caffeine contracture value for MHS pig muscle. Each mean is the average of eight muscle strips, two per animal.

to caffeine testing after biopsy did not significantly affect the caffeine contracture responses, but a tendency for the two-hour samples to produce greater contracture (Table I) and smaller specific caffeine concentration values was observed (Figure 2).

In contrast to the lack of dantrolene effect on halothane or caffeine contractures, a marked effect of dantrolene on the contracture responses to caffeine in the presence of halothane was evident (Table 11). The effect of dantrolene was to increase the contracture response to caffeine in the presence of halothane. There were no significant

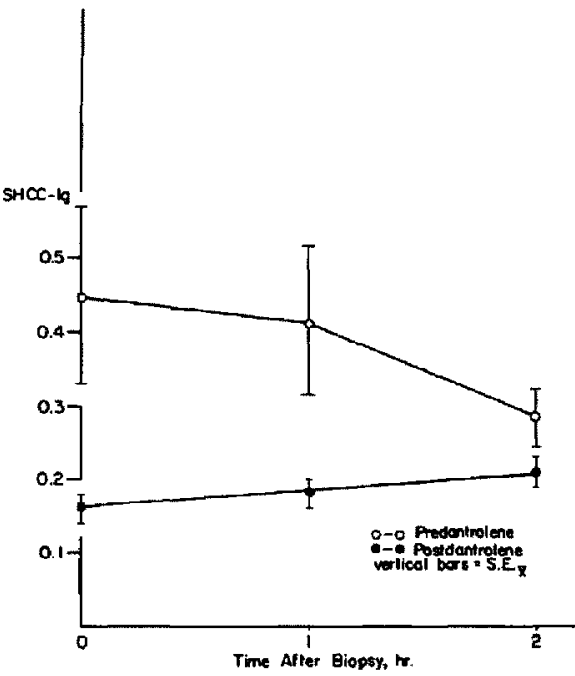

FIGURE 3 Effect of dantrolene and time after biopsy on $1 \mathrm{~g}$ specific caffeine contracture values with halothane, for MHS pig muscle. Each mean is the average of eight muscle strips, two per animal.

differences associated with time after biopsy among specific caffeine concentrations with halothane (Figure 3).

\section{Discussion}

The elective diagnosis of malignant hyperthermia susceptibility is based upon abnormal contracture response of susceptible muscle to halothane and to caffeine with and without halothane..$^{3-6}$ As shown previously, dantrolene applied to muscle strips in vitro eliminated MHS

TABLE II

Effect of Dantrolene and Time After Biopsy on in vitro Halothane-Caffeine Contracture OF MHS MUSCLE

Caffeine Concentration, mM in Presence of Three Per Cent halothane

\begin{tabular}{lccccc}
\hline \hline & $\begin{array}{c}\text { Time after } \\
\text { biopsy, hr }\end{array}$ & \multicolumn{1}{c}{0.1} & 0.25 & 0.50 & 1.0 \\
\hline Predantrolene & Zero & $* 0.5(.03)$ & $0.57(.10)$ & $1.13(.09)$ & $3.01(.48)$ \\
& 1 & $0.13(.08)$ & $0.74(.13)$ & $1.45(.24)$ & $5.00(.64)$ \\
& 2 & $0.11(.07)$ & 0.88 & $2.14(.09)$ & $6.71(.33)$ \\
Postdantrolene & Zero & $0.15(.10)$ & $2.13(.30)$ & $3.90(.42)$ & \\
& 1 & $0.19(.13)$ & $2.17(.18)$ & $5.32(.75)$ & \\
& 2 & $0.13(.10)$ & $1.70(.15)$ & $5.23(.62)$ & \\
\hline
\end{tabular}

-Values are average cumulative contracture tension, $(\mathrm{g})$ and values in parentheses are S.E. $\bar{x}$ Each mean across caffeine concentrations is the average of eight muscle strips, two per animal. 
muscle contracture to halothane and altered the response to caffeine with and without halothane. ${ }^{7-9}$ Based on the in vitro effects of dantrolene on MHS muscle, it could be expected that the effects of dantrolene administered in vivo could be prolonged to the in virro tests of a subsequent biopsy. The present study shows that prior intravenous administration of a prophylactic dose of dantrolene does not alter subsequent in vitro discrimination of susceptible muscle.

Halothane induces contracture of MHS muscle in vitro and this response is uniquely characteristic for muscle from MHS individuals. ${ }^{3-5}$ The lack of effect of prior dantrolene administration on this response is important because it suggests that dantrolene can be administered for malignant hyperthermia prophylaxis without interfering with the diagnostic test. An unexpected result from this study was the increased contracture response to halothane as time from biopsy to time of in virro test increased. Since dantrolene had no effect on halothane contracture and the dantrolene treatment $X$ time interaction was insignificant, an in vitro washout of dantrolene with time after biopsy is precluded. The experimental design of this study cannot preclude other possible time effects such as other drug washout effects or metabolic changes. However. regardless of the reasons for this time effect, the results certainly indicate that time from biopsy to time of in vitro testing should be standardized for MHS diagnostic procedures.

The specific caffeine concentration required to produce a $1 \mathrm{~g}$ contracture of MHS muscle was not significantly altered by prior dantrolene administration or by time after biopsy. This result also supports the use of dantrolene prophylaxis without altering diagnostic discrimination of susceptibility to malignant hyperthermia. It is of interest that time to testing after biopsy had no significant effect on caffeine contracture of MHS muscle. The specific caffeine contracture values after dantrolene treatment appeared to decrease with time after biopsy, while time effects on these values before dantrolene were less apparent (Figure 2). The lack of a significant treatment $X$ time interaction effect precludes a time effect only for dantrolene treated muscle. Whatever the nature of the time effects on halothane contractures, these were not of significance to the caffeine contractures. If a drug washout effect is involved, the drug(s) washed out may be affecting the halothane but not the caffeine effects.

Halothane markedly potentiates muscle contracture response to caffeine, but the mechanism by which this occurs is unknown. ${ }^{6}$ Dantrolene treatment significantly increased MHS muscle response to caffeine in the presence of halothane. The SCC value in the presence of halothane was consequently lower after dantrolene treatment This result is consistent with previous data ( $\mathrm{Nel}$ son, unpublished) which showed that in vitro dantrolene treated MHS muscle has greater contracture response to caffeine plus halothane when the caffeine concentration is greater than $8 \mathrm{mM}$. However, the previous results (Nelson, unpublished) showing that in vitro dantrolene depressed contracture to low doses of caffeine (0.5-4 mM) plus halothane do not correspond to the in vivo dantrolene effects in the present study. We are not able to explain either the in vivo or the in vitro effects of dantrolene on MHS contracture to caffeine plus halothane; but overall, the common result appears to be a protective effect which conserves the contractility of MHS muscle. Regardless of the exact mechanisms involved, dantrolene treatment increased rather than decreased the MHS muscle contracture to caffeine plus halothane.

Based on the results of this study, it is concluded that prior dantrolene treatment does not, affect the in vitro discrimination of malignant hyperthermia susceptibility in the pig by muscle contracture response to halothane. It is not yet known if these results can be extrapolated to man, but if they can, a greater margin of safety for general anaesthesia in association with diagnostic muscle biopsy can be provided by dantrolene.

\section{SUMMARY}

A therapeutic and prophylactic dose of dantrolene administered to malignant hyperthermia-susceptible pigs had no effect on the abnormal in vitro contracture response of subsequent muscle biopsies. The in vitro contracture response of MHS pig muscle to halothane and to caffeine was not altered by prior dantrolene treatment. It is concluded that prior dantrolene administration has no effect on the discrimination of porcine MHS by in vitro pharmacological testing.

\section{RéSUMÉ}

On a administré à des porcs susceptibles d'hyperthermie maligne. une dose de 3.5 $\mathrm{mg} \cdot \mathrm{kg}^{-1}$ de dantrolène dans le but de pro- 
duire une dépression maximale de la contraction provoquée de l'orteil. Des biopsies du muscle droit interne de la cuisse ont été prélevées avant et apres l'administration de la drogue pour évaluer les modifications qu'elle pourrait apporter aux épreuves diagnostiques basées sur l'évaluation in vitro de la contracture du muscle en contact avec l'halothane. la caféine ou une com. binaison de ces deux drogues. Les épreuves de contraction furent réalisées immédiatement, une heure ou deux après chaque biopsie.

Lor's de l'épreuve à l'halothane. le dantrolène n'a eu aucun effet sur la réceptivité du muscle et la contracture se mesurait à $0.8 \mathrm{~g}$ en moyenne avant et à $0.7 \mathrm{~g}$ après traitement. Au contact de lhalothane la contracture augmentait avec la longueur de l'intervale qui séparait le prélèvement de l'épreuve et le dantrolène n'a pas modifié cet effet particulier. La concentration spécifique de caféine nécessaire pour une contracture isométrique mesurée à $1 \mathrm{~g}$ du muscle susceptible à l'hyperthermie maligne $n$ 'a pas été modifiée par le dantrolène $(2.56 \mathrm{mM}$ avant et $2.60 \mathrm{mM}$ après dantrolène). L'intervale entre le prélèvement et l'êpreuve n'a pas affecté de façon significative la réponse à la caféine seule, alors que l'association halothane- caféine augmente l'effet de contracture après dantrolène. On en conclut que l'administration préalable de dantrolène n'a pas d'effet sur le dèroulement des épreuves pharmacologiques in vitro de l'hypothermie maligne.

\section{ACKNowledgement}

The technical assistance of Mr John Finley is gratefully acknowledged.

\section{REFERENCES}

1. Nelson, T.E.. BedelL, D.M. \& Jones, E.W. Porcine malignant hyperthermia: effects of temperature and extracellular calcium concentration on halothane-induced contracture of susceptible skeletal muscle. Anesthesiology 42: 301-306 (1976).

2. Nelson, T.E. \& Fleivellen, E.H. Rationale for dantrolene vs. procainamide for treatment of malignant hyperthermia. Anesthesiology 50 : 118-122(1979).

3. Nelson, T.E.. Austin. K.L. \& Denaormlih. M.A. Screening for malignant hyperpyrexia. Br. J. Anaesth. 49: 169-172 (1977).

4. Moulds. R.F. \& Denborough. M.A. Biochemical basis of malignant hyperpyrexia. Br. Med. J. 2: 241-244 (1974).

5. Ellis, F.R. \& Harriman, D.G. A new screening test for susceptibility to malignant hyperpyrexia. Br. J. Anaesth. 45: 638 (1973).

6. Kalow, W., Britt, B.A.. Terrau, M.E. \& Halst, C. Metabolic error of muscle metabolism after recovery from malignant hyperthermia. Lancet $1: 895-898(1970)$.

7. NELSON, T.E. Unpublished data.

8. Nelson, T,E. Excitation-contraction coupling: a common etiologic pathway for malignant hyperthermia susceptible muscle. In: Second International Sympositm on Malignant Hyperthermia. Edited by Aldrete, J.A. and Britt. B.A.. N.Y., Grune and Stratton, Inc.. pp. 23-35 (1978).

9. ANDERSON, 1.A. \& JONE, E.W. Porcine malignant hyperthermia. Effect of dantrolene sodium on is vitro halothane-induced contracture of susceptible muscle. Anesthesialogy 44: 57-61 (1976).

10. HARRison, G.G. Control of the malignant hyperpyrexic syndrome in MHS swine by dantrolene sodium. Br. J. Anaesth. 47: 62-65 (1975).

11. Gronert, G.A., Milde, J.H. \& Theye, R.A Dantrolene in porcine malignant hyperthermia. Ancsthesiology 44: 488-495 (1976).

12. Hale, G.M., Lucke, J.N. \& Lister, D. Treatment of porcine malignant hyperpyrexia: The successful use of dantrolene in the Pietrain pig. Anaesthesia 32: 472-474 (1977). 